\title{
Sellafield remains at the centre of the storm
}

LIVING with radiation in Britain has come to require the intellectual stamina for digesting a plethora of technical and often conflicting documents. This is the experience of the past few weeks, which have seen the publication of the first report from the newly appointed Committee on Medical Aspects of Radiation in the Environment (COMARE); the government's response to a critical report on waste management from the House of Commons Select Committee on the Environment; and a further slew of documents from the National Radiological Protection Board (NRPB).

COMARE, which owes its existence to a recommendation of the report two years

\section{Paying for old lambs}

Confusion persists in Britain about arrangements for compensating farmers for the consequences of the ban on the sales of lamb after the accident at the Soviet nuclear power station at Chernobyl. Farmers affected, in North Wales and Cumbria, have been told that the British agriculture ministry will pay compensation to farmers able to show they have suffered loss by having to keep lambs off the market for so long that they no longer qualify for the premium prices paid for lean animals.

But suggestions that the British government will pass the bill, which might amount to $£ 10$ million, onto the Soviet government, are premature. That, a spokesman at the agriculture ministry said last week, would be a matter for the Foreign and Commonwealth Office.

Restrictions of the sale of lambs through agricultural markets are being progressively removed, and now apply only to the Lake District region of Cumbria. They were introduced at the beginning of last month because the caesium-134 content of lambs from the affected regions exceeded $1,000 \mathrm{~Bq}$ per $\mathrm{kg}$, a limit adopted by the ministry as an "action level" after an ad hoc meeting of a European Community advisory committee. The Emergency Reference Level recommended by the National Radiological Protection Board (NRPB) earlier this year is ten times as much, or $10,000 \mathrm{~Bq}$ per $\mathrm{kg}$.

As yet, it seems, no British farmer has made a formal application for compensation. There appears to be no plan to compensate farmers for reduced prices from the sales of lamb from farms outside the two affected areas. ago by Sir Douglas Black about the occurrence of excess leukaemia deaths around the Sellafield reprocessing plant, ironically begins its life by correcting in its First Report (HMSO, $£ 4.40$ ) the Black report's calculations.

The unexpectedly high incidence of leukaemia in the neighbourhood of the reprocessing plant, first publicized by a television company, is now accepted as a valid observation which was, in fact, the stimulus for Sir Douglas Black's inquiry. The conclusion of that report was that leukaemia incidence in the neighbourhood of the plant, especially among people born in the $1950 \mathrm{~s}$, was indeed greatly in excess of the expected average incidence but not necessarily inconsistent with random fluctuations within the small population concerned.

The committee is however exercised by the discovery that the Black inquiry, which was provided with an official history of radioactive discharges from the Sellafield plant, including that from the fire in the core of a plutonium-producing reactor in 1957, was not told of an incident in which fission products from spent uranium fuel elements had been released to the environment in 1954 and 1955.

The circumstances are odd, and have come to light because of representations by Dr Derek Jakeman, now a reactor physicist at the Winfrith Heath Research Establishment of the UK Atomic Energy Authority (UKAEA), but an employee at the Sellafield (then called Windscale) establishment in the 1950s. Jakeman was one of two employees who called attention to the unsuspected release of radioactivity from the two plutonium reactors on the basis of measurements of soil from his garden near the plant.

Jakeman said this week that irradiated uranium metal fuel elements occasionally incorrectly discharged from the plutonium reactors in 1954 and 1955 would lodge inaccessibly behind a concrete shield and would be allowed to oxidize in the ambient air. He estimated at the time that several kilograms of uranium and associated fission products would have been discharged in oxide form to the local environment. His revised estimate is that a total of $30 \mathrm{~kg}$ of uranium and its associated fission products would have been released over a period of perhaps two years; a formal report on Jakeman's reconstruction of this leakage will be published by the Winfrith establishment in the next few days.

What concerns COMARE is that infor- mation about this release was not provided to the Black inquiry, and that a search of UKAEA archives since carried out did not uncover a reference to the incident. The committee says that the "way in which these data came to light is unsatisfactory and undermines our confidence in the adequacy and the completeness of the available data". The committee nevertheless accepts that the increased radiation doses to young people living nearby in the 1950 s are at once less than the natural background and insufficient to account for the leukaemia incidence.

The recalculation of the exposure of the Sellafield population to artificial radioactivity has been carried out by NRPB (NRPB-RI7I-Addendum) in the light of the further information about the uncontrolled oxidation of fuel elements in 1954-55, information about other recorded discharges report to the Black inquiry and new assumptions about the rate of absorption of plutonium and americium in the gut which have recently been recommended by the International Commission on Radiological Protection (ICRP). The effect is to increase the expected incidence of leukaemia as a consequence of discharges from the Sellafield plant by roughly two-thirds, giving an expected number of cases of 0.16 among the study population of 1,255 , which is statistically much less than the 4 cases on which controversy continues to centre. NRPB's recalculation also distinguishes between the effects on bone marrow of radiation with high and low linear-energy transfer (LET) in tissues; its report says that although the biological effects of highLET radiation may have been underestimated, supposing that the degree of underestimation would suffice to explain the four known cases of leukaemia would require that the incidence of leukaemia on account of natural radiation would be much greater than is observed away from nuclear plants.

Sellafield is also the chief focus of the British government's reply to the House of Commons select committee's report, which argued on 12 March that the new reprocessing plant being built at Sellafield to handle oxide fuel from pressurized water reactors should be abandoned. The government now says (Radioactive Waste, Cmnd 9852, $£ 3.40$ ) that the financial consequences of abandonment would involve the waste of $£ 600$ million already spent on the plant.

More significantly, the government's response also holds robustly to the view that extracting fissile material from spent uranium fuel is a necessary preparation for the next century "when nuclear power will have an essential contribution to make". In other respects, as in its willingness to specify limits for the discharge of gaseous radioactivity to the atmosphere, the government is conciliatory. 